\title{
Analysis of Cultural Effects on Business Curricular Subject Matter
}

\author{
Vladimir Burčik \\ Comenius University, \\ Bratislava, Slovakia
}

burcik@ilern.sk

\author{
Gary J. DeLorenzo \\ California University of \\ Pennsylvania, California,PA, USA
}

delorenzo@cup.edu

\section{Frederick G. Kohun and Robert Joseph Skovira Robert Morris University, Pittsburgh, PA, USA}

\author{
kohun@rmu.edu; skovira@rmu.edu
}

\begin{abstract}
It has been argued that culture effects how individuals implement, understand, and teach the curriculum of business courses within a society's educational institutions (Burčik, Kohun, \& Skovira, 2007; DeLorenzo, Kohun, \& Skovira, 2006; Hofstede \& Hofstede, 2005). The curricula and their subject matter of business faculties reflect the societies in which the curricula are developed and in which they are taught.

The essay presents a rubric for analyzing this curricular phenomena based on Hofstede and Hofstede's (2005) conception that a society's culture constituted in and presented in individuals' views and routines is determinate of professorial understandings and teachings of business subject matter. In particular, Hofstede's indices on Power Distance, Uncertainty Avoidance is applied to select business curricula from the Slovak Republic and the United States. The analysis includes a rubric of curricular attributes from a convenience sample of select university business programs in the Slovak Republic and the United States for comparative purposes.
\end{abstract}

Keywords. cultural, organizational learning, business, curriculum

\section{Introduction}

It has been argued that culture effects how individuals implement, understand, and teach the curriculum of business courses within a society's educational institutions (Hofstede \& Hofstede, 2005; DeLorenzo, Kohun, \& Skovira, 2006; Burčik, Kohun, \& Skovira, 2007). The curricula and

Material published as part of this publication, either on-line or in print, is copyrighted by the Informing Science Institute. Permission to make digital or paper copy of part or all of these works for personal or classroom use is granted without fee provided that the copies are not made or distributed for profit or commercial advantage AND that copies 1) bear this notice in full and 2) give the full citation on the first page. It is permissible to abstract these works so long as credit is given. To copy in all other cases or to republish or to post on a server or to redistribute to lists requires specific permission and payment of a fee. Contact Publisher@InformingScience.org to request redistribution permission. their subject matter of business faculties reflect the societies in which the curricula are developed and in which they are taught.

The essay presents a rubric for analyzing this curricular phenomena based on Hofstede and Hofstede's (2005) conception that a society's culture constituted in and presented in individuals' views and routines is determinate of professo- 
rial understandings and teachings of business subject matter. The rubric is a framework for analyzing the effects of culture on curricular adaptations, and accreditation efforts globally. The essay begins also an analyses of selected curricula from the Slovak Republic and the United States.

\section{The Global and the Local}

The global is always at odds with the local. Friedman (2000) used the metaphors of "Lexus" and "Olive Tree" to evoke the conflictive and tension-filled relationships between the push of modernity and the pull of tradition. Friedman's concept of global emphasizes that there is a unifying and homogenizing system of markets, societies, and information networks worldwide which are leveling and standardizing forces; the push of modernity. Standardizing forces are homogenizing.

An aspect of the global is the movement of AACSB International to spread across local situations to impose educational standards of quality on societies' institutionalized business curricula.

\section{The Cultural Matrix}

Culture is the concept we use to explain seemingly patterned behaviors from the perspective of a social group. Culture is the complex matrix of behavior; a shared system of valued sensibilities and practices which influence individuals' habitual ways of saying and doing things. Culture is all the things taken-for-granted and presumed as a basis for communication. Culture refers to the usual ways of doing and saying. Culture is the common sense in situations and their affairs and activities. People spend all their time learning how and why to act, learning what emotion goes with what cognitive affair, learning how to use language, how to see things, hear things, and touch things, learning things so well that they become habits of experience. Becoming acculturated and socialized are developmental and evolutionary affairs. Culture is the shared habits of representation, reference, and inference. Every person has an idiosyncratic take on the habits learned (or each person thinks he or she does.) A typical habit learned is the habit of dependency (and independency.) Part of this phenomenon is an ability and competence at influencing the sense of a situation as defined by the web of social relationships. Being independent or dependent are important, but being able to influence how situations are finished is more important. Humans learn about this phenomenon even before they can name it. Hofstede and Hofstede (2005) call this the power distance dimension of a culture. Power distance is an important explanatory concept of behavior. Another learned cultural habit is that of dealing with "up-in-the-air" situations or ambiguous situations. This is Hofstede and Hofstede's (2005) dimension of uncertainty avoidance. A combination of power distance and uncertainty avoidance tacitly focuses the cultural ground for people expounding theories of management and marketing. Following Hofstede and Hofstede, a particular society's power distance index and uncertainty avoidance index explain managerial styles, organizational governance, information flows and use, and the scope of authority and responsibility. It follows that a society's relative position to another society in terms of the indices also describes, analyzes and explains business theories used and taught by business faculties to explain to their students how corporate interests work in the "real world." (Gannon, 2001; Geertz, 1973; Hofstede, 2001; Hofstede \& Hofstede, 2005; Hooker, 2003; Rowe \& Mason, 1989; Trompenaars, 1994; Trompenaars \& Woolliams, 2003).

\section{Power and Ambiguity}

As a hypothesis of situational behavior, power distance allows an explanation of culturally influenced behavior and theories of behavior. Power distance is defined as how "...the less powerful members of institutions and organizations within a country expect and accept that power is dis- 
tributed unequally." (italics in original) (Dooley, 2003; Hofstede, 2001, p. xix; Hofstede \& Hofstede, 2005, p. 46; Hooker, 2003; Huang, Lu, \& Wong, 2003; Mead, 1994; Steming \& Hammer, 1992). It is also an explanation of the expectations of the powerful or those in positions of power (and influence); their acceptance is an important as anyone's acceptance. From within a culture, expectations, acceptances, and uses are natural. Power distance in a particular culture is a way of interpreting relationships between and among people generally. There is a continuum from small to large power distance and use in situations.

As a hypothesis of situations and their affairs, uncertainty avoidance is an explanation of culturally influenced attitudes towards types of situations and other people and things whose interactivity create the situations. Uncertainty avoidance is defined as a cultural perspective reflecting "...the extent to which the members of a culture feel threatened by ambiguous or unknown situations." (italics in original) (Cyert \& March, 1963/1992; Hofstede, 1983; Hofstede \& Hofstede, 2005, p. 167; March, 1994; Umanath \& Campbell, 1997). As Hofstede (2001) puts it, uncertainty avoidance "...is the extent to which a culture programs its members to feel either uncomfortable or comfortable in unstructured situations" (p. xix). Uncertainty avoidance is a way of explaining characteristics of situations and relationships such as control, conflict and competition, or consensus. The strong to weak uncertainty avoidance continuum describes and elaborates the situational contexts: weak may be conflictive; strong may be consensual. The situations are conflictive pushing for consensus or agreeable pulling for conflict (Connor \& Worley, 1991; Hofstede, 1994b; Mead, 1994).

\section{Analytical Rubric}

There are four rubrics of analysis: market, machine, family, and pyramid. They are heuristical conceptions for analysis and explanation.

\section{Market}

The market rubric is built on the notion that the situation's power distance is small and its uncertainty avoidance is weak. There is a preferred relationship among members of a culture which even in corporate settings is one of basic equality, and independence. Power resides in the position and not the person; there are checks-and-balance policies in place. Corporate authority and accountability are affairs spread through the organization, even when on paper there is a top and a bottom to the organization chart. While things may be "rational" or planned, activities and tasks are charged to teams and task forces in a decentralizing use of information. Corporate governance is federal; a republican view of command and control with a sense of hierarchy based in the situation and role played. Managerial styles are analytical (problem solvers,) conceptual (visionaries,) and social (communicators.) communicative style in most cases is low context; things are spelled out and meanings are operationalized (Davenport, 1997; Davenport, Eccles, \& Prusak, 1992; Hofstede \& Hofstede, 2005; Rowe \& Mason, 1989).

\section{Machine}

The machine rubric translates a small power distance and strong uncertainty avoidance pattern of actions in situations. Authority and accountability are distributed but activities and tasks are situationally controlled. The flow and access to and use of information is controlled. Corporate governance is a matter of loyalty to the organization through being loyal to the leaders or by being viewed as "team members." It is feudal. Contrarian thinking is subversive but following implicit or explicit directives or corporate goals is prudent loyalty. Managerial styles are analytical (problem solvers and therefore team players) and directive (setting goals and tasks for loyal teams to accomplish.) Communicative style is high context: there is a reliance on goals and policies to op- 
erationalize meanings (Davenport, 1997; Davenport, Eccles, \& Prusak, 1992; Hofstede \& Hofstede, 2005; Rowe \& Mason, 1989).

\section{Family}

The family rubric is based on large power distance and weak uncertainty avoidance. Authority and accountability are centered on the leaders who embody power. Activities and tasks are situationally unstructured. Corporate governance is described by a person's or a committee's span of command and control. Loyalty to the person in charge is important to the well being of the organization. Governance is monarchical and feudal. Managerial style is a combination of being directive (setting goals and tasks) and social (being a communicator of the goals and results desired.) Communicative style is high context (Davenport, 1997; Davenport, Eccles, \& Prusak, 1992; Hofstede \& Hofstede, 2005; Rowe \& Mason, 1989)

\section{Pyramid}

The pyramid rubric is grounded in a large power distance and strong uncertainty avoidance situation. Authority and accountability are highly centralized in managerial positions. Work flow is structured by goals, policies, and tasks to be achieved. Access ot and use of information is controlled by the ends-in-view or the results to be achieved. Corporate governance is monarchical and feudal in nature; it is top-down and based on a felt loyalty to managers. The managerial style consists of directive (setting goals and results to be achieved) and analytical (viewing things as problems to be solved.) communicative style is low context (Davenport, 1997; Davenport, Eccles, \& Prusak, 1992; Hofstede \& Hofstede, 2005; Rowe \& Mason, 1989)

\section{Culturally Effected Curricula}

A society's culture influences at the local level a course of study in business, its students, and its business faculty. Theories of management, corporate governance, and marketing are derivatives of a society's culture, which, in this paper, are manifested in the frames of power distance and uncertainty avoidance. Accreditation bodies promulgate curricula aimed at providing a universal (if not global) frame of reference for the development and implementation of "best practices" in business studies. The curriculum of any business faculty is always local; Friedman's (2000) "Olive Trees." The local situation frames even AACSB International's model curriculum. Even as this model channels thinking and action globally, the "water" in the channels represents local translations of particular business theories. The frames of power distance and uncertainty avoidance are sluices in the channels of accreditation.

While the frames of power distance and uncertainty avoidance impact social conscientiousness, universities continue to offer curriculum to address AACSB accreditation and the global marketplace. Our intent is to evaluate the curriculum at four (4) universities (two in the U.S.A. and two in Europe) to determine if each curriculum has a "local" frame on course content that addresses power distance and uncertainty avoidance across multiple cultures, specifically the U.S.A. and Europe, or if the curriculum has a "globalized" frame that is more homogenized with little content on culture frames for the U.S.A. and Europe.

The following lists, by university, the courses and brief descriptions on content for the Faculty of Management at Comenius University in Slovakia for an undergraduate program in business, and at Harvard and Stanford Universities in the U.S.A. for MBA programs.

While the undergraduate and graduate programs in Europe all have the same courses required in an American AACSB accredited university school of business, they appear to reflect the same topics, use similar books, and have the same course titles. However, by examining the syllabi and detailed descriptions the courses have basic yet intrinsic differences as suggested by Hofstede. 
The courses examined included management, marketing, banking, economics, and human resources management - courses found in a typical school of business common body of knowledge. While reading the following course descriptions taken from the university's website, the course uses the nomenclature of its American counterpart with no indication the context is the same. Further examination reveals a European, or Slovak perspective. While framed in a global economy, there is focus and emphasis on the localized culture. In the following descriptions taken from Comenius University's Faculty of Management website, the differences from the typical American counterpart course is highlighted to emphasize the localized nature of the course.

\section{Comenius University in Slovakia}

\begin{tabular}{|l|l|l|}
\hline \multicolumn{2}{|l|}{ Bank Marketing } & KMAR \\
\hline ES/ ECTS 3 & $2 \mathrm{~h} / 7,9$ & $\mathrm{C}$ \\
\hline
\end{tabular}

The aim of the subject is to provide a main framework of bank marketing to students of specializations Marketing and Financial Management. The stress is on the effective implementation of marketing strategies into the banks. Also in Slovakia, the banking industry moves from a highly controlled industry to an industry characterized by more aggressive competition.

Koraus, A : Marketing v bankovnictve a poist'ovnictve, Brasilava: Sprint 2000.

Channon, D. F.: Bank Strategic Management and Marketing. London: Wiley, 1994

Channon, D. F.: Global Banking Strategy. London: Wiley, 1990.

Dwight - Ritter: Relationship Banking. N.Y.C.: 1996.

Wright, D.: Bank Marketing for the 90's. N.Y.C.: 1996.

ProQuest - database.

Biatec, Trend.

\section{BUSINESS IN EUROPE}

\begin{tabular}{|l|l|l|}
\hline CS/ ECTS 5 & $4 \mathrm{~h} / 6$ & C 40/ E 60 \\
\hline
\end{tabular}

The aim of the course is to provide students with knowledge of doing business and entrepreneurship in Europe and international business, which they could effectively utilize in their future managerial practice or/and entrepreneurship.

Benes Vlastislav a koletiv: Zahranicni obchol GRADA 2004.

Hill, Charles W. L.: International Business. McGraw-Hill, Irwin, 2003

Jimenez Guillermo: Zaklady exportu a importu. SOPK Bratislava 1999.

Johnson Debra and Colin Turner: European Business. Routledge, 2000.

JUDr. Ing. Pavol Kopal: Doing Business in the Solvak Repulbic. Slovak Chamber of Commerce and Industry, 1996.

Piskanin, A. Bajzikova, L': Podikanie v Europe Ofprint Bratislava, 2001/.

Sir Leon Brittan, Baroness Chalker, Richard Needham: Doing Business with the West. Kogan Page Ltd. 1993. 


\begin{tabular}{|l|l|l|}
\hline \multicolumn{2}{|l|}{ Economics IV } & KFE \\
\hline CS/ ECTS 5 & $4 \mathrm{~h} / 4$ & C 30/ E 70 \\
\hline
\end{tabular}

The last part of the course covers capita select that deserves special attention like economic policy (monetary, fiscal and supply side), exchange rate systems, regulation, environmental problems, the European Union, inflation and unemployment. Some remarks are made concerning the distinction between capitalism and socialism.

C. R. Krugman, M. Obstfeld: International Economics, Additon- Wesley, 1997

\begin{tabular}{|l|l|l|}
\hline \multicolumn{2}{|l|}{ ENGLISH FOR MANAGERS - I-IV } & KIS \\
\hline CS/ ECTS 3 & $2 \mathrm{~h} / 1,2,3,4$ & C 50/ E 50 \\
\hline
\end{tabular}

This upper-intermediate Business English course for students of management follows the communications and functional approach, with an emphasis on both fluency and accuracy. The course is focusing on developing and improving language skills needed for future managers. Students practice and extend language skills such as listening and reading by means of activities in their English class where the latest articles on business and management issues are presented and discussed.

Communication skills are extended with emphasis on speaking (e.g. role-plays, minitalks, discussions, presentations), and on clarity of written work as extra-class activity (e.g. composition of business letters, memoranda, reports, etc.).

Furthermore, cognitive knowledge of the English Grammar is developing as required by the students at upper-intermediate and advanced level. Introducing, studying and learning new vocabulary is developed in detail, particularly new words and phrases associated with Business English. Learning to learn vocabulary, to define terms adequately and to use them appropriately can contribute to getting a general overview of modern business.

Tullis, G., Trappe, T.: New Insights into Business, Longman 1999 


\begin{tabular}{|l|l|l|}
\hline \multicolumn{2}{|l|}{ GLOBAL NETWORKS } & KIS \\
\hline ES/ ECTS 3 & $2 \mathrm{~h} / 3,4$ & $\mathrm{C}$ \\
\hline
\end{tabular}

The main aim of this course is to grasp the fundamental principles of the internet, its functions, use in business, connectivity and creation of web pages. Part of the course is the creation of personal web pages with two levels of immersion.

Prof. dr. R.T. Griffiths Internet for Historians, History of the Internet, The Development of the Internet

Michael Dillon, Jon Postel's Legacy: A Keeper of Lists, An Internet Arbiter

(C) State of Victoria (Department of Education, Employment \& Training) Initiative of the SOFWeb Project

http://www.sofweb.vic.edu.au/internet/index.htm

Chelsea Martin: INTERNET HISTORY

http://www.sofweb.vic.edu.au/internet/index.htm

http://www.vicomtech.com/

http://mag-nify.educ.monash.edu.au/Wingate/

\begin{tabular}{|c|c|c|}
\hline \multicolumn{2}{|c|}{ INTERCULTURAL MANAGEMENT } & \multirow{2}{*}{\begin{tabular}{|l} 
KSP \\
C \\
\end{tabular}} \\
\hline ES/ ECTS 2 & $2 \mathrm{~h} / 6$ & \\
\hline \multicolumn{3}{|c|}{$\begin{array}{l}\text { The course shows importance, depth and influence of cultural specifics in various countries and geo- } \\
\text { graphic areas on management and business practices and helps to prepare students for professional } \\
\text { business interaction with these countries. These regions covered are: Europe, North America, South } \\
\text { America, Arabic countries and Israel, Asia, Australia and Africa. }\end{array}$} \\
\hline \multicolumn{3}{|c|}{$\begin{array}{l}\text { HAMPDEN-TURNER, Ch. - TROMPENAARS, A.: Building Cross-Cultural Competence. Chiches- } \\
\text { ter : John Wiley \& Sons, 2000. ISBN: 0-471-49527-1. }\end{array}$} \\
\hline \multicolumn{3}{|c|}{ www.executiveplanet.com } \\
\hline \multicolumn{3}{|c|}{ www.finetravel.com } \\
\hline \multicolumn{3}{|c|}{ www.geert-hofstede.com/index.shtml } \\
\hline www.busine & & \\
\hline
\end{tabular}




\begin{tabular}{|c|c|c|}
\hline \multicolumn{2}{|c|}{$\begin{array}{l}\text { International Human Resource } \\
\text { Management }\end{array}$} & KMAN \\
\hline CS/ ECTS 6 & $4 \mathrm{~h} / 8$ & C 50/ E 50 \\
\hline
\end{tabular}

This course provides a survey of human resource practices in Europe in comparison with other district regions (USA \& Asia). The objective of the course is to examine different approaches to HRM.

Hollinshead, G. \& Leat, M. 1994. Human Resource Management (an international and comparative perspective on the employment relationship). Pitman Publishing.

Kirkbrride, P.S. 1994. Human Resource Management in Europe (perspectives for the 1990's). Routledge.

Sparrow, P \& Hiltrop J-M. 1994. European Human Resource Management in Transition. Prentice Hall.

The International Journal of Human Resource Management

Journal of International Business Studies

Human Resource Management

Journal of Human Resource Management

Human Resource Management Journal

Journal of Human Resource Management, Bratislava, Slovak Republic

\begin{tabular}{|l|l|l|}
\hline \multicolumn{2}{|l|}{ International Economic Relations } & KFE \\
\hline CS/ ECTS 5 & $4 \mathrm{~h} / 6$ & $\mathrm{C}, \mathrm{E}$ \\
\hline
\end{tabular}

The standard course in international economics is divided into microeconomic and macroeconomic sections. The microeconomic section discusses trade theory and trade policy. Trade theory examines the basis for trades and the gains from trade. Trade policy studies the reasons for and consequences of obstructing trade with tariffs, quotas, and other measures. "the single most consistent mission of international economics," according to Krugman and Obstfield, "has been to analyze the effect of... protectionist policies." The macroeconomic section of a standard course in international economics deals with the balance of payments and adjustment in the balance of payments or, open economy macroeconomics. Classical and neo-classical theories of comparative advantages, international trade and economic growth, national accounts and balance-of-payments adjustment, exchange rate determination, capital mobility, economic integration.

P. Krugman, M. Obstfield: International Economics 


\begin{tabular}{|l|l|l|}
\hline \multicolumn{2}{|l|}{ International Commercial Law } & KFE \\
\hline ES/ ECTS 3 & $2 \mathrm{~h} / 5,6$ & $\mathrm{C}$ \\
\hline
\end{tabular}

This course will focus on issues concerning the law and practice of international trade. The material will focus on contracts and the international sale of goods; the legal forms of business that international trading takes place under and related issues concerning these arrangements. The course will focus on the law of the European community, the United States, Slovakia and various treaties.

\begin{tabular}{|c|c|c|}
\hline \multicolumn{2}{|c|}{ International Environmental Policy } & KFE \\
\hline CS/ ECTS 3 & $2 \mathrm{~h} / 8$ & $\mathrm{C}, \mathrm{E}$ \\
\hline \multicolumn{3}{|c|}{$\begin{array}{l}\text { Economical and social development of the world and global ecological problems. International re } \\
\text { quirements for ecologization of economic development. Global political and economical interests and } \\
\text { international ecology policy. World ecology problems in north-south and west-east relations. UN } \\
\text { ecology policy. Ecological policy of USA, EU, Asian countries. International environmental agree- } \\
\text { ments and conventions. }\end{array}$} \\
\hline
\end{tabular}

\begin{tabular}{|c|c|c|}
\hline \multicolumn{2}{|c|}{ International Finance } & KFE \\
\hline ES/ ECTS 3 & $2 \mathrm{~h} / 9$ & C \\
\hline \multicolumn{3}{|c|}{$\begin{array}{l}\text { The lecture combines theoretical lectures and practice through experience and relevant documents } \\
\text { analysis (e.g. European Commission's reports). The objective of this programme is to provide the stu- } \\
\text { dents with a framework and tools that help them to better understand the development of the European } \\
\text { Union and the set up of a coherent financial markets framework. }\end{array}$} \\
\hline
\end{tabular}




\begin{tabular}{|c|c|c|}
\hline \multicolumn{2}{|c|}{ International Marketing } & KMAR \\
\hline CS/ ECTS 6 & $4 \mathrm{~h} / 9$ & C 30/ E 70 \\
\hline Prerequisites: & \multicolumn{2}{|c|}{ Marketing Management, Marketing Research } \\
\hline \multicolumn{3}{|c|}{$\begin{array}{l}\text { The course helps to understand and enables to use all the information about international marketing. It } \\
\text { contains application of marketing in international marketing area. It is based on assumption that mar- } \\
\text { keting in various countries have differences, which need special attention. Presentations and seminars } \\
\text { should introduce and explain relations in world market area. Students should study international mar- } \\
\text { kets; methods for finding the strategies for these markets, as well as application of marketing mix fac- } \\
\text { tors according to international context. }\end{array}$} \\
\hline \multicolumn{3}{|c|}{ Štarchoň, P.: Medzinárodný marketing I. Vybrané časti. Pracovný materiál. 2005} \\
\hline \multicolumn{3}{|c|}{ Světlík, J.: Marketing pro evropský trh. Praha: Grada Publishing 2003.} \\
\hline \multicolumn{3}{|c|}{ Terpstra, V.: International Dimensions of Marketing. Wardsworth Publishing Company 1993.} \\
\hline \multicolumn{3}{|c|}{ Paliwoda, J. S. - Ryands, J.K.: International Marketing Reader. London: Routledge 1995.} \\
\hline \multicolumn{3}{|c|}{ Brassington, F. - Pettitt, S.: Principles of Marketing. Pitman Publishing 2003.} \\
\hline \multicolumn{3}{|c|}{ Usunier, J.C.: Marketing Across Cultures. Prentice Hall Europe 1996.} \\
\hline \multirow{2}{*}{\multicolumn{3}{|c|}{$\begin{array}{l}\text { Welford, R. - Prescott, K.: European Business. An Issue-Based Approach. Pitman Publishing } 1996 . \\
\text { Larsen, H. H.: Cases in Marketing. London: Sage Publications } 1997 .\end{array}$}} \\
\hline & & \\
\hline \multicolumn{3}{|c|}{ ProQuest - database } \\
\hline \multicolumn{3}{|c|}{ Trend, Profit, Journal of International Marketing } \\
\hline
\end{tabular}

\begin{tabular}{|l|l|l|}
\hline \multicolumn{2}{|l|}{ International Trade and $\boldsymbol{E U}$} & KFE \\
\hline CS/ ECTS 6 & $4 \mathrm{~h} / 8$ & C 30/ E 70 \\
\hline
\end{tabular}

Theory of international business and trade. The importance of international trade in qualitative development in the Slovak republic and its entrance into the European union. The role of international trade in the reproduction processes. The importance of science and technical processes in the economy development of the Slovak republic. The importance of trade policy concerning the strategy of international economic integration. The commercial operations and the commercial negotiations in international business. The structure of commercial operations and the effectiveness of international business.

\begin{tabular}{|c|c|c|}
\hline \multicolumn{2}{|c|}{$\begin{array}{l}\text { Management of EU Programs and } \\
\text { Projects }\end{array}$} & \multirow{2}{*}{\begin{tabular}{|l|} 
KIS \\
C \\
\end{tabular}} \\
\hline ES/ ECTS 3 & $2 \mathrm{~h} / 7,9$ & \\
\hline \multicolumn{3}{|c|}{$\begin{array}{l}\text { Projects financed by EU. } \\
\text { Management for Development Foundation, Project Management and Programme Administration } \\
\text { Course, Ede, The Netherlands, 1995, 1999. }\end{array}$} \\
\hline
\end{tabular}




\begin{tabular}{|c|c|c|}
\hline \multicolumn{2}{|c|}{$\begin{array}{l}\text { Managerial Skills in the English-speaking } \\
\text { Environment I, II }\end{array}$} & KIS \\
\hline ES/ ECTS 3 & $2 \mathrm{~h} / 5,6$ & $\mathrm{C}$ \\
\hline
\end{tabular}

This is a skills based course for students of management at an advanced level of English. The course develops students' managerial skills required for meetings, negotiations, presentations, office talks and socializing at an international level. The emphasis is on improving students' oral communication skills in order to perform better and more effectively in the world of international business. The course pays high attention to increasing social and cultural awareness of the business world, often the most difficult area for students.

Cotton, D., Robbins, S.: Business Class, Longman 1999

Wallwork, A.: Business Options, Oxford University Press, 2001

\begin{tabular}{|c|c|c|}
\hline \multicolumn{2}{|c|}{ Organisational Cultures } & \multirow{2}{*}{\begin{tabular}{|l|} 
KMAN \\
$\mathrm{C}$ \\
\end{tabular}} \\
\hline ES/ ECTS 3 & $2 \mathrm{~h} / 5$ & \\
\hline Prerequisites: & \multicolumn{2}{|c|}{ Organisational Culture - Theory } \\
\hline \multicolumn{3}{|c|}{ Aim of the Course: } \\
\hline \multicolumn{3}{|c|}{ To understand the differences in HRM of individual EU countries. } \\
\hline \multicolumn{3}{|c|}{ Mercado, S.-Welford,R.-Prescott,K.: European Business, Pearson Education Ltd. 2001} \\
\hline \multicolumn{3}{|c|}{ Mole, J.: Mind Your Manners, Nicholas Brealey Publishing 1993} \\
\hline \multicolumn{3}{|c|}{ Crane, R.: European Business Cultures, Prentice Hall 2000} \\
\hline \multicolumn{3}{|c|}{ Hampden-Turner,C.-Trompenaars,F.: Building Cross-cultural Competence, John Wiley 2000} \\
\hline \multicolumn{3}{|c|}{ Lewis,R. D.: When Cultures Collide, Nicholas Brealey Publishing 1999} \\
\hline \multicolumn{3}{|c|}{ Lewis,R. D.: The Cultural Imperative, Nicholas Brealey Publishing 2003} \\
\hline
\end{tabular}




\begin{tabular}{|c|c|c|}
\hline \multicolumn{2}{|c|}{$\begin{array}{l}\text { Organisational Cultures (European } \\
\text { features) }\end{array}$} & \multirow{2}{*}{\begin{tabular}{|l|} 
KMAN \\
C 50/ E 50
\end{tabular}} \\
\hline CS/ ECTS 6 & $4 \mathrm{~h} / 8$ & \\
\hline Prerequisites: & \multicolumn{2}{|c|}{ Organisational Culture - Theory } \\
\hline \multicolumn{3}{|c|}{ Aim of the Course: } \\
\hline \multicolumn{3}{|c|}{ To understand the differences in HRM of individual EU countries. } \\
\hline \multicolumn{3}{|c|}{ Mercado,S.-Welford,R.-Prescott,K.: European Business, Pearson Education Ltd. 2001} \\
\hline \multicolumn{3}{|c|}{ Mole, J.: Mind Your Manners, Nicholas Brealey Publishing 1993} \\
\hline \multicolumn{3}{|c|}{ Crane,R.: European Business Cultures, Prentice Hall 2000} \\
\hline \multicolumn{3}{|c|}{ Hampden-Turner,C.-Trompenaars,F.: Building Cross-cultural Competence, John Wiley 2000} \\
\hline \multicolumn{3}{|c|}{ Lewis,R.D.: When Cultures Collide, Nicholas Brealey Publishing 1999} \\
\hline \multicolumn{3}{|c|}{ Lewis,R.D.: The Cultural Imperative, Nicholas Brealey Publishing 2003} \\
\hline
\end{tabular}

\begin{tabular}{|l|l|l|}
\hline \multicolumn{2}{|l|}{ Regional Economics and Policy of EU } & KFE \\
\hline CS/ ECTS 3 & $2 \mathrm{~h} / 9$ & $\mathrm{C}$ \\
\hline
\end{tabular}

Armstrong, H., Taylor, J.: Regional Economics and Policy, Second Edition, Harvester Wheatsheaf, New York London Toronto, 1993

From the sample course descriptions listed above, a few observations can be made. The Slovak business program has numerous business courses very specific to the content with respect to the business subjects described. Secondly, globalization is not a generalized segment of the business education, but an economic reality necessitating curricular immersion. Focus is on cultural differences, language and communication-particularly in English as the language of business, and policy related to doing business with the EU as well as the USA. It is quite noticeable that this Slovak business curriculum offers many levels of language courses of European Union countries as well as English.

Globalization is inherent to this curriculum. It is not a forced add on but rather an engineered practical solution to the economic and social reality that defines the nature of business. It is possible in the Slovak context to contend with the practical issues of doing business in a European market by being able to offer so courses that presumably serve a well defined need. Furthermore, the curriculum is not restricted to a select common body of knowledge-but goes beyond to address the localized business needs to strengthen or provide an advantage in the global world as defined from a Slovak perspective. 
AACSB - U.S.A.Matrix on M.B.A. course content and descriptions --- required curriculum:

\section{A. Harvard - Term 1:}

\begin{tabular}{|c|c|c|}
\hline Management & Marketing & Org Behavior \\
\hline $\begin{array}{l}\text { Technology and Operations } \\
\text { Management (TOM). This } \\
\text { course enables students to } \\
\text { develop the skills and concepts } \\
\text { needed to ensure the ongoing } \\
\text { contribution of a firm's opera- } \\
\text { tions to its competitive position. } \\
\text { It helps them to understand the } \\
\text { complex processes underlying } \\
\text { the development and manufac- } \\
\text { ture of products as well as the } \\
\text { creation and delivery of ser- } \\
\text { vices. } \\
\text { Topics encompass: } \\
\text { - Process analysis } \\
\text { - Cross-functional and } \\
\text { cross-firm integration } \\
\text { - Product development } \\
\text { - Technormation technology } \\
\text { tions strategy }\end{array}$ & $\begin{array}{l}\text { Marketing. The objectives of } \\
\text { this course are to demonstrate } \\
\text { the role of marketing in the } \\
\text { company; to explore the rela- } \\
\text { tionship of marketing to other } \\
\text { functions; and to show how } \\
\text { effective marketing builds on a } \\
\text { thorough understanding of } \\
\text { buyer behavior to create value } \\
\text { for customers. } \\
\text { Students learn how to: } \\
\text { Make marketing deci- } \\
\text { sions in the context of } \\
\text { general management. } \\
\text { Control the elements } \\
\text { of the marketing mix- } \\
\text { product policy, chan- } \\
\text { nels of distribution, } \\
\text { communication, and } \\
\text { pricing-to satisfy cus- } \\
\text { tomer needs profitably. } \\
\text { Use this knowledge in } \\
\text { a brand management } \\
\text { simulation. The course } \\
\text { culminates in an ex- } \\
\text { amination of the evolu- } \\
\text { tion of marketing, par- } \\
\text { ticularly focusing on } \\
\text { opportunities pre- } \\
\text { sented by the Internet. }\end{array}$ & 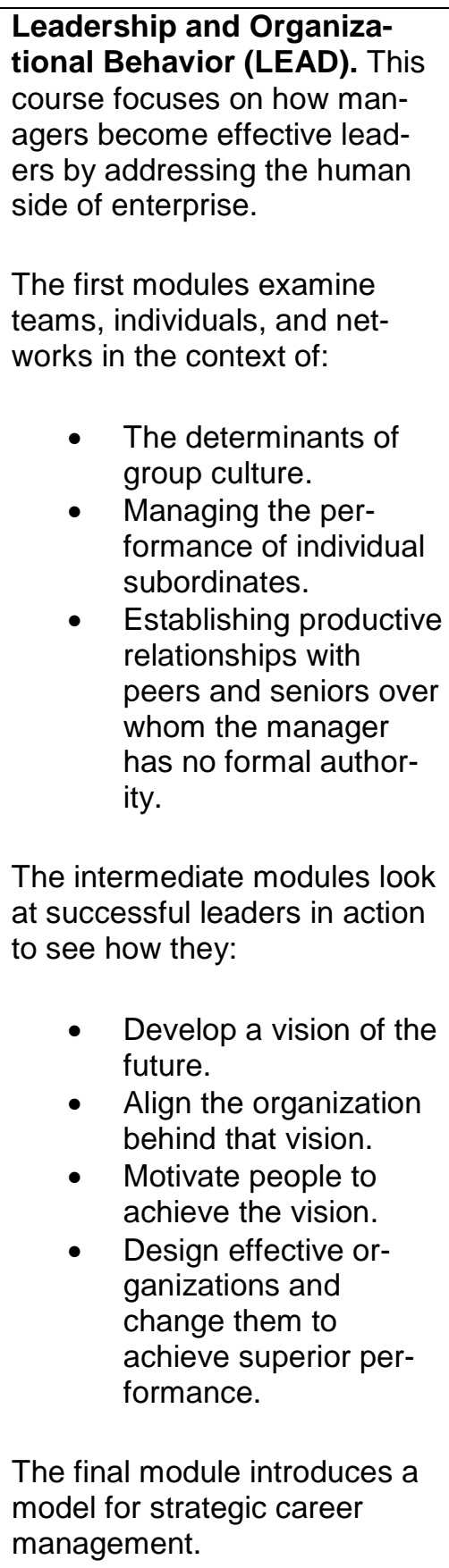 \\
\hline
\end{tabular}




\section{Harvard - Term 2}

\begin{tabular}{|c|c|c|}
\hline Management & Marketing & Org Behavior \\
\hline $\begin{array}{l}\text { The Entrepreneurial Man- } \\
\text { ager. This course addresses } \\
\text { the issues faced by managers } \\
\text { who wish to turn opportunity } \\
\text { into viable organizations that } \\
\text { create value, and empowers } \\
\text { students to develop their own } \\
\text { approaches, guidelines, and } \\
\text { skills for being entrepreneurial } \\
\text { managers. The course teaches } \\
\text { students how to: } \\
\text { - Identify potentially } \\
\text { valuable opportunities. } \\
\text { Obtain the resources } \\
\text { necessary to pursue } \\
\text { an opportunity and to } \\
\text { create an entrepreneu- } \\
\text { rial organization. } \\
\text { Manage the entrepre- } \\
\text { neurial organization } \\
\text { once it has been es- } \\
\text { tablished. } \\
\text { Grow the business into } \\
\text { a sustainable enter- } \\
\text { prise. } \\
\text { Create and harvest } \\
\text { value for the organiza- } \\
\text { tion's stakeholders. } \\
\text { - A firm's operative envi- } \\
\text { ronment and how to } \\
\text { sustain competitive } \\
\text { advantage. } \\
\text { How to generate value } \\
\text { for customers by de- } \\
\text { signing the optimum } \\
\text { configuration of the } \\
\text { product mix and func- } \\
\text { tional activities. } \\
\text { students develop the skills for } \\
\text { formulating strategy. It } \\
\text { provides an understanding of: } \\
\text { This course helps }\end{array}$ & $\begin{array}{l}\text { Negotiation. This course fo- } \\
\text { cuses on developing negotia- } \\
\text { tion skills and analysis. At its } \\
\text { core are carefully structured } \\
\text { negotiation exercises. } \\
\text { Students learn: } \\
\text { - How to effectively ne- } \\
\text { gotiate through the use } \\
\text { of exercises, cases, } \\
\text { readings, and videos. } \\
\text { How external and in- } \\
\text { ternal negotiation has } \\
\text { become a way of life } \\
\text { for effective managers } \\
\text { in a constantly chang- } \\
\text { ing business environ- } \\
\text { ment. }\end{array}$ & $\begin{array}{l}\text { Leadership and Corporate } \\
\text { Accountability. In this } \\
\text { course, students learn about } \\
\text { the complex responsibilities } \\
\text { facing business leaders today } \\
\text { Through cases about difficult } \\
\text { managerial decisions, the } \\
\text { course examines the legal, } \\
\text { ethical, and economic } \\
\text { responsibilities of corporate } \\
\text { leaders. It also teaches } \\
\text { students about management } \\
\text { and governance systems } \\
\text { leaders can use to promote } \\
\text { responsible conduct by } \\
\text { companies and their } \\
\text { employees, and shows how } \\
\text { personal values can play a } \\
\text { critical role in effective } \\
\text { leadership. }\end{array}$ \\
\hline
\end{tabular}


B. Stanford-Terms 1 \& 2:

\begin{tabular}{|c|c|c|}
\hline Management & Marketing & Org Behavior \\
\hline $\begin{array}{l}\text { The Global Context of Man- } \\
\text { agement. The objectives of } \\
\text { this course are twofold: to help } \\
\text { develop your understanding of } \\
\text { the cultural, economic, finan- } \\
\text { cial, and political forces that } \\
\text { drive the global marketplace } \\
\text { and individual markets within } \\
\text { the broader market, and to } \\
\text { provide you with a framework } \\
\text { for, and experience in, learning } \\
\text { quickly about specific markets. } \\
\text { You will understand the impor- } \\
\text { tant questions to ask and an- } \\
\text { swer when contemplating en- } \\
\text { tering or allying in a new mar- } \\
\text { ket. } \\
\text { Critical Analytical Thinking. } \\
\text { (CAT) will address issues that } \\
\text { transcend any single discipline } \\
\text { or function of management. In } \\
\text { 14-16 person sections, you will } \\
\text { analyze, write about, and de- } \\
\text { bate fundamental issues, } \\
\text { questions, and phenomena } \\
\text { that arise in many forms in } \\
\text { management. You will explore } \\
\text { these critical issues broadly, as } \\
\text { well as hone your analytic and } \\
\text { persuasive skills. CAT will en- } \\
\text { hance your ability to identify } \\
\text { critical questions when explor- } \\
\text { ing a new business issue, to } \\
\text { parse issues, to develop rea- } \\
\text { soned positions, and to make } \\
\text { compelling arguments. CAT } \\
\text { also will help you explore the } \\
\text { principles and ideals that you } \\
\text { will seek to uphold as a leader. }\end{array}$ & $\begin{array}{l}\text { Marketing. These } \\
\text { courses introduce you } \\
\text { to the substantive and } \\
\text { procedural aspects of } \\
\text { marketing manage- } \\
\text { ment. You'll learn } \\
\text { about analyzing the } \\
\text { needs and wants of } \\
\text { potential customers, } \\
\text { and creating and de- } \\
\text { livering goods and ser- } \\
\text { vices profitably. Be- } \\
\text { yond the base-level } \\
\text { option, one alternative } \\
\text { uses learning-by-doing } \\
\text { (through simulations), } \\
\text { with an emphasis on } \\
\text { business-to-business } \\
\text { marketing; a more ad- } \\
\text { vanced option stresses } \\
\text { the use of advanced } \\
\text { statistical techniques in } \\
\text { the practice of market- } \\
\text { ing. }\end{array}$ & $\begin{array}{l}\text { Human Resources } \\
\text { (HR) } \\
\text { Provides the frame- } \\
\text { work for understanding } \\
\text { and thinking strategi- } \\
\text { cally about employ- } \\
\text { ment relations and the } \\
\text { management of human } \\
\text { resources in organiza- } \\
\text { tions. This area draws } \\
\text { on insights from the } \\
\text { social sciences to ex- } \\
\text { plore how employment } \\
\text { relations are influ- } \\
\text { enced by cultural, eco- } \\
\text { nomic, legal, psycho- } \\
\text { logical, and social } \\
\text { forces. The base-level } \\
\text { option emphasizes } \\
\text { four fundamental top- } \\
\text { ics: (1) the selection of } \\
\text { employees; (2) the de- } \\
\text { velopment of their } \\
\text { skills (human capital); } \\
\text { (3) the use of pay to } \\
\text { motivate workers, and } \\
\text { other types of incen- } \\
\text { tives; and (4) the or- } \\
\text { ganization of the work- } \\
\text { force into teams, hier- } \\
\text { archies, and so forth. } \\
\text { Options allow you to } \\
\text { specialize in HR prac- } \\
\text { tices for high-skill } \\
\text { "knowledge" workers } \\
\text { or how HR practices } \\
\text { vary across the globe. } \\
\text { Managing Groups } \\
\text { and Teams } \\
\text { This course introduces } \\
\text { you to the structures } \\
\text { and processes that af- } \\
\text { fect group perform- } \\
\text { ance and highlights } \\
\text { some of the common } \\
\text { pitfalls associated with } \\
\text { working in teams. Top- } \\
\text { ics include team cul- } \\
\text { ture, fostering creativ- } \\
\text { ity and coordination, } \\
\text { making group deci- }\end{array}$ \\
\hline
\end{tabular}




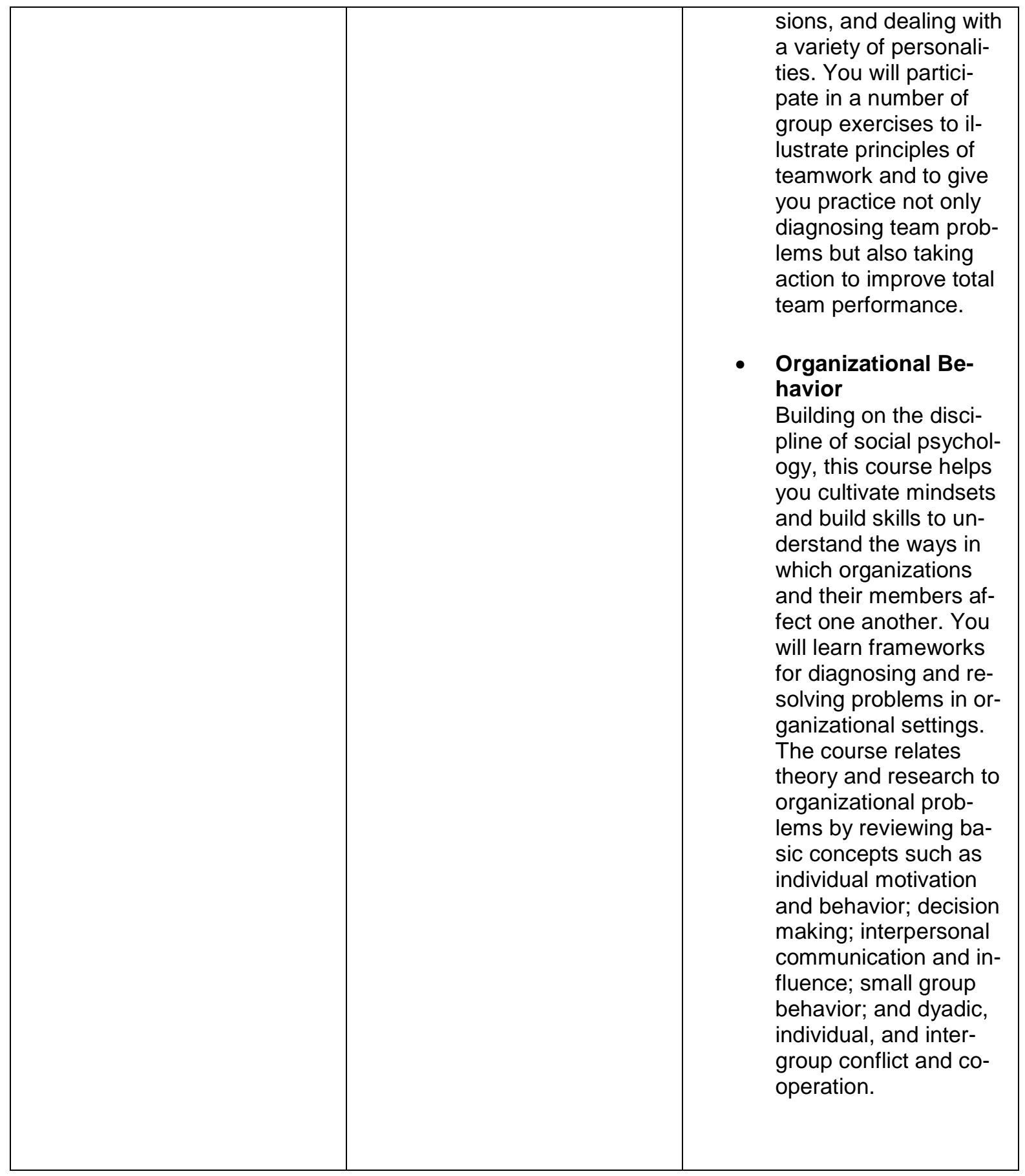

The business programs at Harvard and Stanford Universities while representative of two of the top business programs in the United States reflect a topical and breadth approach to business issues and skills. The approach is centered on theory and appears to be universally generic with respect to its treatment of globalization. By the nature of curricular standardization, the course offerings are limited in number and coverage. 


\section{Findings}

An analysis of curriculum at the Faculty of Management at Comenius University in Slovakia, and of the MBA programs Harvard and Stanford Universities in the U.S.A. revealed the following insights:

- The curriculum for all four universities addresses the AACSB's international model curriculum.

- The curriulum for all four universities addresses basic principles in the areas of management, marketing and organizational behavior.

The differences between the European and the U.S.A. universities were noticeable on some courses in the areas of management, marketing and organizational behavior:

- The curriculum at Harvard and Stanford are more "global" and generic in nature with little content on specific social and cultural comparisons. As an example, Stanford's "Human Resources", "Managing Groups and Teams" and "Organizational Behavior" courses address employment relations, group performance and the understanding of the organization and its affect on members with little global cultural comparisons.

- The curriculum at Comenius is more "local" with content that addresses Slovakian, European and U.S.A. social consciousness. The "International Human Resource Management" course addresses practices in Europe in comparison with other district regions (U.S.A. \& Asia).

- The curriculum at Comenius addresses management concepts for both Europe and the U.S.A. with courses such as "Business in Europe" and "English for Managers" as examples while the U.S.A. universities offered little course content on business in Europe.

The question that surfaces as the core of Hofstede's work is , can there truly be a standard curriculum of business born of the USA that can, in fact, be localized and relevant to globalization in a frame other than the EU, China, Japan, and the USA? The EU consists of how many localized business cultures forced to operate at a EU level, a global beyond the bounds of Europe, as well as at a local level. Each facet of business incorporates power distance, ambiguity, and a context of market, machine, family, and pyramid-- to name a few of the localized cultural dimensions.

This paper explored the viability of curricular standardization in a global economy based on an inherent frame of localized culture. While curriculum may have the same naming conventions, texts, and general topics, localized interest and focus may skew the content away from the business model established through international accreditation standards. These standards, while focused on a business frame developed in the context of one culture with intended objectivity and cultural neutrality, may reflect only one small aspect of the business arena. While no curriculum can be complete and universally comprehensive, the inherent inclusion of localized culture will inevitably be melded into the curriculum either implicitly as in the case of the two premiere universities in the United States, or explicitly as in the case of Comenius University in the Slovak Republic.

\section{References}

Burčik, V. Kohun, F. G., \& Skovira, R. J. (2007). Analyzing the affect of culture on curricular content: A research conception. Issues in Informing Science and Information Technology, 4, 381-393. Retrieved from http://proceedings.informingscience.org/InSITE2007/IISITv4p381-393Burc373.pdf

Connor, P. E. \& Worley, C. H. (1991). Managing organizational stress. Business Quarterly, 56(1), 61-67. 
Cyert, R. M., \& March, J. G. $(1962,1992)$. A behavioral theory of the firm $\left(2^{\text {nd }}\right.$ ed.). Cambridge, MA: Blackwell.

Davenport, T. H., Eccles, R. G., \& Prusak, L. (1992). Information politics. Sloan Management Review, 34(1), 53-65.

Davenport, T. H. (with Prusak, L.). (1997). Information ecology: Mastering the information and knowledge environment. Boston, MA: Harvard Business School Press.

DeLorenzo, G., Kohun, F. \& Skovira, R. J. (2006). Analyzing the affect of globalizing business education on managerial and organizational theories: A framework for research. Proceedings of the $7^{\text {th }}$ International Conference of the Faculty of Management Koper, University of Primorska, Slovenia, 7, 1833 1840.

Dooley, R. (2003). Four cultures, one company: Achieving corporate excellence through working cultural complexity. Organization Development Journal, 21(2), 52-66.

Friedman, T. L. (2000). The Lexus and the olive tree. New York: Farrar, Straus and Giroux.

Gannon, M. J. (2001). Understanding global cultures: Metaphorical journeys through 23 nations. Thousand Oaks, CA: Sage.

Geertz, C. (1973). The interpretation of cultures. New York: Basic Books.

Goffman, E. (1974). Frame analysis: An essay on the organization of experience. Cambridge: Harvard University Press.

Hofstede, G. (Ed.). (1979). Futures for work: A book of original readings. The Hague: Matinus Nyhoff.

Hofstede, G. (1983). National cultures in four dimensions: A research-based theory of cultural differences among nations. International Studies of Management and Organizations, 13(1-2), 46-74.

Hofstede, G. (1994a). Management scientists are human. Management Science, 40(1), 4-13.

Hofstede, G. (1994b). Uncommon sense about organizations: Cases, studies, and field observations. Thousand Oaks, CA: Sage.

Hofstede, G. (2001). Culture's consequences: Comparing values, behaviors, institutions, and organizations across nations (2nd ed.). Thousand Oaks, CA: Sage.

Hofstede, G. \& Hofstede, G. J. (2005). Cultures and organizations: Software of the mind. New York: McGraw-Hill.

Hooker, J. (2003). Working across cultures. Stanford, CA: Stanford University Press.

Huang, L., Lu, M., \& Wong, B. K. (2003). The impact of power distance on email acceptance. Journal of Computer Information Systems, 44(1), 93-101.

Joiner, T. A. (2001). The influence of national culture and organizational culture alignment on job stress and performance: Evidence from Greece. Journal of Managerial Psychology, 16(3), 229-242.

Kim, D., Pan, Y. \& Park, H. S. (1998 September). High- versus low-context cultures: A comparison of Chinese, Korean, and American cultures. Psychology \& Marketing, 15(6), 507-521.

Klein, B. D. (2002, Fall). Teaching information management to graduate non-IT majors. The Journal of Computer Information Systems, 43(1), 42-47.

Leonard, N. H., Scholl, R. W. \& Kowalski, K. B. (1999). Information processing style and decision making. Journal of Organizational Behavior, 20, 407-420.

March, J. G., \& Olsen, J. P. (1976). Ambiguity and choice in organizations. Bergen Oslo Tromso: Universitetsforlaget.

March, J. G. (with Heath, C). (1994). A primer on decision making. New York: The Free Press.

Margerison, C. J. (1974). Managerial problem solving. London: McGraw-Hill. 
Mead, R. (1994). International management: Cross-cultural dimensions. Cambridge, MA: Blackwell.

Norman, D. A. (1988). The design of everyday things. New York: Currency Doubleday.

Peterson, M. F., Smith, P. B., Akande, A., Ayestaran, S., Bocher, S., Callan, V. et al. (1995 April). Role conflict, ambiguity, and overload: A 21-nation study. Academy of Management Journal, 38(2), 429452.

Raelin, J. A. (1986). The clash of cultures: Managers and professionals. Boston, MA: Harvard Business School Press.

Rowe, A. J. \& Mason, R. O. (1989). Managing with style: A guide to understanding, assessing, and improving decision making. San Francisco and London: Jossey-Bass.

Simon, H. A. (1977). The new science of management decisions. Englewood Cliffs, NJ: Prentice-Hall.

Skovira, R. J. (2004). Using informational landscape as a model to understand information use and design within organizations. Issues in Information Systems, V(1), 308-314.

Steming, B. W. \& Hammer, M. R. (1992). Cultural baggage and the adapt ion of expatriate American and Japanese managers. Management International Review 72(1), 77-89.

Strassman, P. A. (1995). The politics of information management. New Canaan, CN: The Information Economics Press.

Thatcher, J. R., Srite, M., Stepina, L. P., \& Liu, Y. (2003). Culture, overload and personal innovativeness with information technology; Extending the nomological net. The Journal of Computer Information Systems, 44(1), 74-81.

Trompenaars, F. (1994). Riding the waves of culture: Understanding diversity in global business. London: The Economist Books.

Trompenaars, F. \& Woolliams, P. (2003). Business across cultures. Chichester, England: Capstone.

Umanath, N. S. \& Campbell, T. L. (1997). Differential diffusion of information systems technology in multinational enterprises: A research model. Information Resources Management Journal, 7(1), 6-18.

\section{Biographies}

PhDr. Vladimír Burčík PhD., Director of Academy of Communication, multimedia projects consultant at graphic studio Mr. Design. He gives lectures at the Department of Psychology at the Faculty of Arts, Comenius University, and at the Department of Design at the Faculty of Fine Arts; specialises in CI, corporate communication, human computer interaction and www design; co-author of a monograph (Internet v riadení a obchode firmy) and of a textbook (Psychodiagnostika dospelých), author of many studies and programmes on CI, published in Slovakia as well as abroad. He worked on creating a corporate identity for the companies Slovakofarma, Milex Schärdinger, Slovenské design centrum, Palma, Rajo, Volkswagen, Všeobecná úverová banka, Ludová banka, Západoslovenská energetika, Telenor Slovakia, Eunet, EuroTel a S\&T Slovakia. He was the member of the jury of EUROPRIX in 1999. He is a member of the Board of directors of the World Summit Award (World Summit on Information Society).

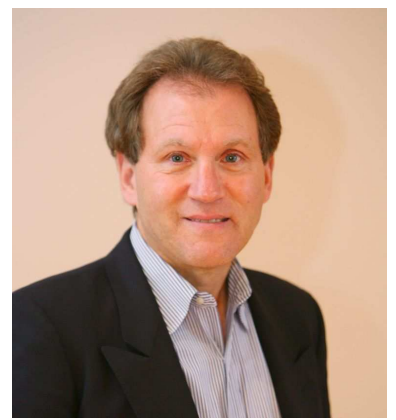

Gary J. DeLorenzo, D.Sc., Assistant Professor of Computer Information Systems in the Department of Mathematics and Computer Science at California University of Pennsylvania USA teaches undergraduate courses including systems analysis, project management, database design and web application development. He is a visiting professor at Robert Morris University, Pittsburgh, PA USA for the Doctor of Science program teaching data warehousing and data mining. Dr. DeLorenzo's research interests include service learning for students outside of the traditional classroom environment and the cultural affect 
and impact of technology within business organizations.

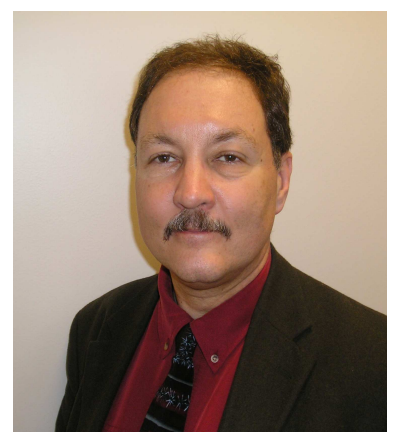

Frederick G. Kohun, Ph.D., Associate Dean and Professor of Computer and Information Systems in the School of Communications and Information Systems at Robert Morris University in Pittsburgh, Pennsylvania has more that 30 years experience as a professor, department head, and academic administrator in the information systems field. He holds a bachelor degree in economics from Georgetown University, graduate degrees in economics and information science, from the University of Pittsburgh, and a Ph.D. in applied history in technology from Carnegie Mellon University. At Robert Morris University he led the design and implementation of eight technology based academic programs at the undergraduate and graduate level (including a doctoral program) as well as the attainment of ABET-CAC accreditation $\mathrm{He}$ is known both nationally and internationally from his numerous publications and presentations, and active involvement as an accreditation evaluator and team leader.

Robert Joseph Skovira, Ph.D., Professor of Computer and Information Systems in the Department of Computer and Information Systems, School of Communications and Information Systems, at Robert Morris University, Pittsburgh PA USA teaches undergraduate and graduate (MS) courses including Java Programming, Secure Programming, Knowledge Management, Global, Economic, Social, and Ethical Issues of Computing, Decision Support Systems, Information Design, and Ethical and Legal Issues of Technology. In the Doctor of Science program he teaches Ethnography of Information Systems. He was a visiting professor at Comenius University, Bratislava, Slovakia, in 1997 and 2006. Dr. Skovira's research interests include information and information system use within organizations (politics of information, information system bias, secure programming), cultural and moral frameworks, decision making and knowledge mapping, and information design and thinking visually 